\section{The outward urge}

\section{The Sun, the Genome and the Internet, Tools of Scientific \\ Revolutions \\ by Freeman Dyson \\ Oxford University Press: 1999. 124 pp. \\ $\$ 22, \mathfrak{E} 15.99$}

\section{Walter Gratzer}

"There's been a lot of progress since I was young," declared Ogden Nash, "but it's going in the wrong direction." Freeman Dyson will have none of that. Now in his mid-seventies, his concern for the future of humankind remains as lively as ever, and his optimism as invigorating. He has never been one to wait until his feet are wet before thinking up ways to stop the ship sinking. He was sufficiently exercised about the Earth's long-term prospects to moot a scheme for shifting it into a more salubrious orbit, and he even devised a scheme for evading the Big Crunch, should this eventuate in $10^{31}$ years or so, by way of an escape into a parallel universe.

One of his preoccupations now is with the practice and economics of space travel, for, as he shows, the US space programme has been direly misconceived and has by its reckless profligacy strangled other worthy activities, such as terrestrial astronomy. The mistake was to devote NASA's huge resources to putting a handful of people into low orbits, and such extravagances as bringing back lumps of rock from Mars, when nature has already left us generous supplies of the same material in the form of meteorites, mostly still reposing in the Arctic ice. Had the effort instead gone into developing more efficient space vehicles, driven, for instance, by laser propulsion or ram jets, there might even now be a community of explorers living on the Moon, and finding ways of adapting to the rigours of the environment.

Dyson's guess, based on a typical interval between discovery of a new land (America in 1492) and its settlement by outsiders (the arrival of the Mayflower), is that colonization of space could begin in about 2085 . A selfsustaining ecology will follow the development of genetically engineered 'warmblooded' (that is to say, heat-generating) trees to give warmth and shelter, as well as fuel and other useful products, secreted from their roots.

The settlement of space will become inevitable, Dyson believes, if only because human cloning and gene manipulation are also inevitable - for then human evolution will be given a sharp nudge and the new species of Homo that will emerge will have no desire at all to share one modestly appointed planet. So they will search for friendly corners of the cosmos: a moon of Jupiter, perhaps, or (most likely, Dyson thinks) the

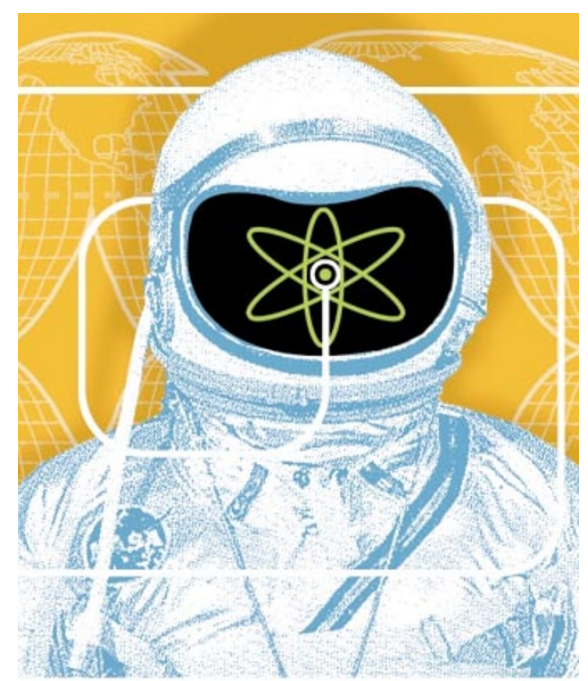

archipelago of watery comets that make up the Kuiper Belt, or even the more distant Oort Cloud. Communities will spring up with libraries, concert halls and other amenities of civilized existence. And, no doubt, the yellow arches of McDonald's will greet the spaceships when they touch down. "One planet," Dyson concludes firmly, "is not enough."

Well, as the sage said: "Don't never prophesy unless you know", and Dyson concedes in his introduction that "experts, when they try to forecast the future, are usually wrong". Dyson is assuredly an expert: he has put his stamp on an unparalleled range of topics in mathematics, physics and technology. Jeremy Bernstein, physicist and writer, describing a casual but decisive intervention by Dyson in an intractable mathematical problem with which he was grappling, remarked that he could not conceive of how it must feel "to think with that rapidity and clarity ... Does everybody else appear to be going in slow motion?" But this is not all, for Dyson has also established himself, by his earlier books and articles, as a startlingly original social thinker and a proselytizer for science of rare panache and style.

This collection of his most recent cogitations is based on a series of four lectures given at the New York Public Library. The title reflects the three areas of research that he believes may dominate the next century.

Chapter one leads off with a brief discourse on how science has evolved and where it is heading. Although a theoretician, Dyson holds that the enterprise owes more to the spirit of the craftsman (like his boilermaker grandfather, with whom he feels a close kinship) than the philosopher. He believes scientists should develop their own tools, rather than buy them from instrument manufacturers, as he berates biologists for doing.

His strictures may cause some gnashing of teeth among the HUGOnauts, for instance, when he instructs them that wet chemistry is a crude, inefficient and reprehensibly expensive way to sequence DNA: he says the opera- tion should be done on single molecules, degraded sequentially from one end, the liberated nucleotides passing into a mass spectrometer to be identified at the rate of one per millisecond. The exercise would then be complete in weeks, not decades, and the value of the project would be vastly enhanced because it would continue, with nominal added cost, to produce more genomic sequences. The priority should have been to develop such instruments - desk-top sequencers for all - and not to launch an enormous, labour-intensive programme, hobbled by the political imperative of a fixed target date. Dyson draws the parallel with the similarly inefficient, politically driven Apollo programme, which came to an end because it was not economically sustainable.

Dyson's arguments are illuminating, even if his strictures are sometimes less than just. Among biologists he makes one exception to his generalization - Fred Sanger. But Sanger did not develop apparatus: his methods of sequencing were the very apotheosis of wet chemistry. The miracle (as it must seem to the younger generation) of the achievements that brought him two Nobel prizes was that they employed little more equipment than a supply of filter paper. Biologists (depending on how one defines them) did, however, extend the frontiers of X-ray crystallography. As for the X-ray microscope - another bench-top tool, which, Dyson suggests, should supplant that crystallography - some fairly strenuous efforts have indeed been (and are being) made to construct one that works to any effect. And if biologists had had to master the skills in physics and engineering to build their own 800-MHz NMR spectrometers, there might have been little time left over for solving structures - no trivial task either.

Dyson's concerns now are centred on what technology might do to bring about a more equitable society. He supports, for instance, a charitable organization called SELF (Solar Electric Light Fund), which is developing cheap solar storage cells to bring electric light to isolated villages. Technology, he argues, has been for us a liberating force, which has done away with the tyranny of domestic service. You might be persuaded that the developed world, at least, is peopled only by the haves and the have-mores, if you were unaware of the widening income gap and the emergence of a disaffected population earning its crust by servicing the demands of the rich. Dyson recognizes that, in the poor and overpopulated countries, technology has served only to distance the privileged minority even further from the undereducated masses; he ponders the question of how the Internet and the WorldWide Web, which are already creating a commercial jungle and erecting ever-higher social barriers, might be tamed and made to serve the ideals of social justice. 
In his epilogue, Dyson ruminates on the ascendancy of machines in our lives. A watershed for him was the defeat of Gary Kasparov by the chess-playing computer, Deep Blue, in 1997, a profoundly dispiriting event for many of us. Inevitable, says Dyson, and, of course, viewed as art succumbing to brute megabytes, tragic. But even here Dyson sees the promise of something greater to come, of art combining with machine to produce a new and deeper beauty. Let us hope so.

So, as the Reverend Sydney Smith observed during a time of trial, "cheerfulness will keep breaking through". "The game of evolution", Dyson assures us in his peroration, "will in future be played by humans and machines playing together. The landscape of cyberspace offers us as much scope for artistic creation as the landscape of a chessboard."

You may not be entirely persuaded by these assurances, but you will certainly feel the better for a bracing hour or two in Freeman Dyson's company.

Walter Gratzer is at the Randall Institute,

King's College, 26-29 Drury Lane,

London WC2B 5RL, UK.

\section{Turning evening into morning}

\section{Time of our Lives}

by Tom Kirkwood

Weidenfeld \& Nicolson: 1998. 287 pp. $£ 20$

\section{John Bayley}

It's a grand life if you don't weaken, as they used to say. Or if you don't get anything wrong with you. In the old days you almost invariably did. TB, cancer, hypertension, pneumonia above all - they could carry you off without much fuss or bother between the fifth and seventh decades of life. But now, says Tom Kirkwood, we ought to become more conscious of the fact that those once almost inevitable shorteners of our lives don't come round for us any more. We should draw a deep breath and make the most of what used to be the evening of our lives. Make it a new morning.

Kirkwood's hearty tone and vigorous mode of exposition are agreeable to nonscientists, even if they do not necessarily grasp all the implications of a scientific argument. Take the little matter of cell ageing, on which much of the general optimism of Kirkwood's thesis depends. He tells the story of the conceited though charismatic French surgeon Alexis Carrel, a Nobel prizewinner who demonstrated that cells outside the body could be kept alive indefinitely in a properly maintained culture, and continue to grow. This seemed good news until Paul Moorhead and Leonard Hayflick demonstrated in their turn that actual body cells appear to be subject to what became known

as the Hayflick limit, the point beyond which cell reduplication did not continue. Could this be because cell ageing and final extinction are programmed as part of the ageing process? In other words, even if we escape the more obvious maladies of mortality, will we die just because our cells give up?

To help lay readers grasp the point, Kirkwood takes the analogy of an airliner hurtling down the runway towards take-off. Should something be still at fault after the elaborate pre-flight checks, a red light will come on in the cockpit, the crew will be alert-

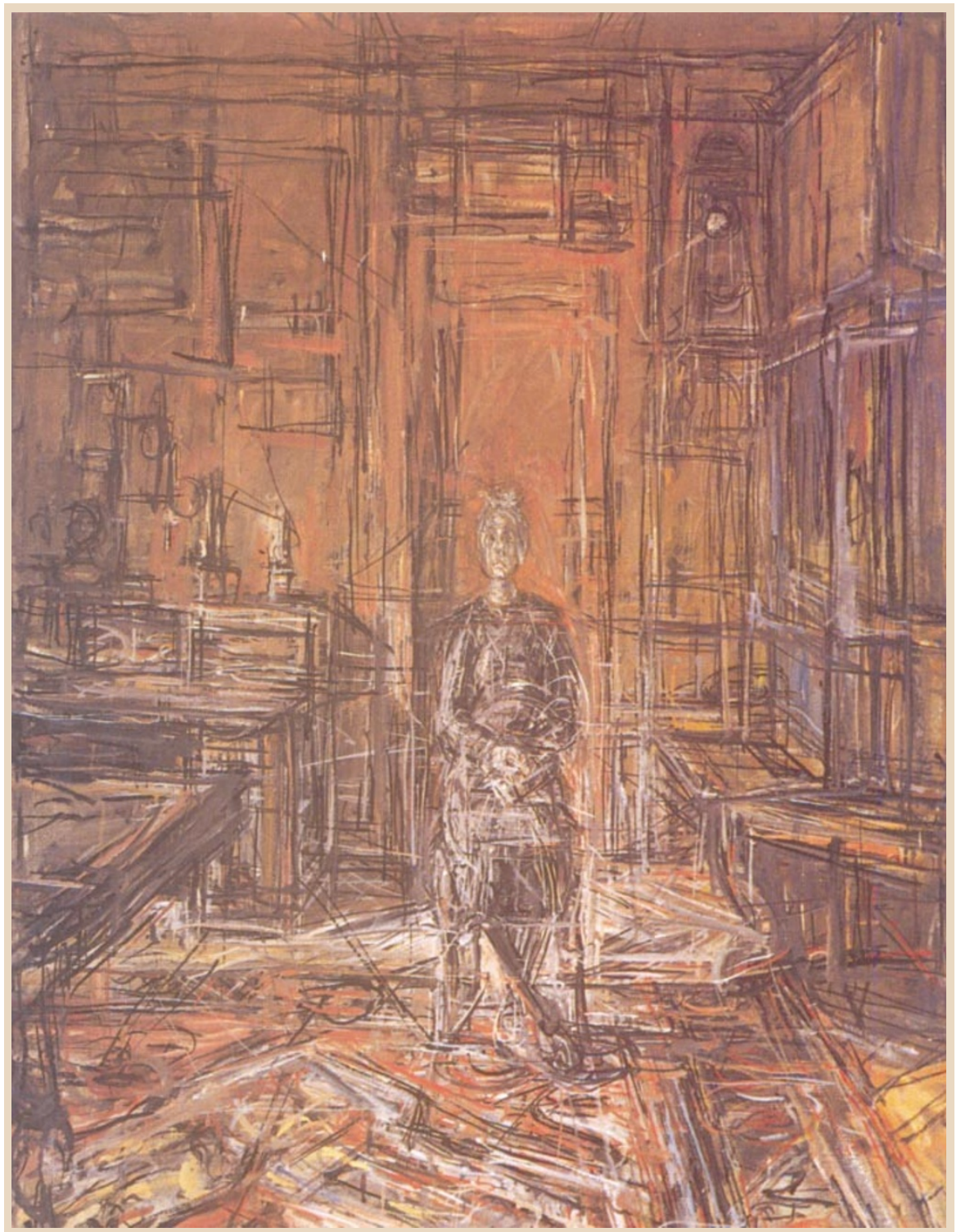

\section{Mind where you put your molecules}

Although Memory: From Mind to Molecules by Larry Squire and Eric Kandel is 69th in the Scientific American Library series (\$34.95, $£ 23.95$ ), it is highly individual. The book is a deftly crafted tour of the study of memory from a brief history of the science, via synapses and neurophysiology, to psychology and what the authors refer to as "the biological basis of individuality". And all this in ten short chapters. ed and the flight aborted. But a wholly clueless outsider might draw the conclusion that the red light was itself the cause of the problem. Cell ageing, that is to say, may not be programmed, but may be the result of random damage or accident over a cumulative period, which will finally have the result of the whole immensely complex system packing up.

I am not convinced that this argument is particularly good news for septuagenarians who may be hoping to enjoy the time of their lives. What may be good news scientifically is
As ever, Kandel and Squire write superbly even for the vaguely interested non-specialist. To crown it all, each chapter is fronted by a modern painting, the relevance of which is valiantly argued by the caption. Alberto Giacometti worked in cycles, creating from memory and then destroying successive works to produce a final version, such as "The artist's mother" (1950) shown here and fronting chapter 10. 